\title{
The Effectiveness of a Law and Society's Affluence: The Paradox of Cyprian Legislation's Reform
}

\author{
Dr. Theofanis Karagiorgos ${ }^{1}$, Dr. Dimitrios Melas ${ }^{2}$, Loucas Fasitsas ${ }^{3}$
}

\begin{abstract}
:
The purpose of this research is to show and to analyze the problems that appeared after the Cyprus legislative change on the $1^{\text {st }}$ January 2003 and mainly to point out the reactions of the shareholders of the off - shore companies, due to the changes of the tax legislation. Our theoretical model considers that a law in the Capital Market is effective, if it increases the expected social prosperity. In our analysis we examined the Bayesian model approach of the effectiveness of the law whose base was to analyze the data supports of the opinion from the asked company consultants.
\end{abstract}

Keywords:

Tax Evasion, Taxation, Greece, Cyprus, Off Shore Companies, Bayesian Study

\footnotetext{
${ }^{I}$ Associate Professor and Head of the Department of Business Administration, University of Macedonia, Greece, e-mail: karagth@uom.gr

${ }^{1}$ PhD MBA, Department of Business Administration, University of Macedonia, Greece, e-mail:melasdim@uom.gr.

${ }^{I}$ MSc, Department of S.S.R.U. University of City, London, PhD Candidate in Department of Applied Informatics, University of Macedonia.e-mail: Fasotsas_l@yahoo.gr.
} 


\section{Introduction}

According to fundamental economic principle, states institute laws in order to improve society's affluence (Besley, 2006). Consequently a law is effective if it achieves this goal (Karagiorgos, 2003). The Cyprian legislation's institution of offshore companies had without dispute been the most beneficiary for the country. Specifically, Cyprus has introduced the estate of "offshore business" (Giles, 2004) so as to promote the country as an international business hub. The term «offshore business»» refers to juridical persons whose beneficiary proprietors do not stay in Cyprus and their incomes proceed from activities out of the country. Moreover, were not allowed to offer products or services to Cyprus, either to resident population of the country or occasional. In addition, it was not allowed to these companies to act as intermediaries to trading of foreign products in Cyprus or to work on export of Cyprian products.

Till the end of December 2002 there had been totally registered more than 45,000 offshore companies with the purpose of management and control of enterprising activities out of Cyprus and about 11,800 shipping companies with the aim of registration ships under Cyprian flag (Central Bank of Cyprus, 2001). 81\% from these companies came from Europe and 9\% from USA and Canada. It is remarked that more than 15,000 offshore companies completely acted in international market (Iliades, Pashalidis, Hatzianastasiou, 2003). A part of 1,200 from those companies employed staff and had set up accomplished offices in Cyprus ${ }^{4}$.

The Cyprian income in foreign exchange from the offshore businesses during 2002 was important running up to 668 million euro and forming the $6.6 \%$ of gross national product. In this amount, the contribution of shipping administration, which is estimated at $30 \%$ (Patsalides \& Associates, 2003), was significant.

\section{Tax Reform in Cyprus}

Since 1/1/2003 and after the Cyprian tax reform in July 2002, legislative system changed as far as it concerns offshore business; especially ring fencing for activities only out of Cyprus, which was applied to offshore companies, was revoked ((Patsalides \& Associates, 2003). It is remarked that the new tax system is entirely conformed to directions and guidelines of European Union and Organization for Economic Co-operation and Development (OECD) (PriceWaterhouseCoopers, 2003).

\footnotetext{
${ }^{4}$ Thessaloniki Chamber of Commerce and Industry, 18 June 2004
} 
Specifically ${ }^{5}$ :

- There is no difference between offshore business and home companies and further more the entry of Cyprian companies to the first category is permitted.

Offshore business can be registered in Cyprus in any of the following types:

- Private Limited Company registered in Cyprus

- Branch of Foreign Company

- Co-operative

- Almost 98\% of the registered offshore business is Private Limited Companies registered in Cyprus.

A company is considered as tax resident of Cyprus if the control and management takes place in the country.

- Single corporate tax $10 \%$ is initiated (minimum requisite tax rate by Brussels) for all the registered companies in Cyprus (offshore and home companies) and it concerns taxable profits which come from commercial activities whether all other net income taxes with single rate $15 \%$. Betweenseason was given to the offshore companies which had income during 2001 exclusively from external or it is expected to have incomes which have not arisen till $31^{\text {st }}$ December 2001 due to the kind of their businesses in order to decide whether they will change to Cyprian companies or to terminate their activities as off shore companies. These companies have the right to continue to be taxed selectively with rate $4.25 \%$ till $31 / 12 / 2005$. It is pointed that until 31/12/2005 the companies' tax rate was for Cyprian companies $20 \%$ for taxable profits up to 40,000 Cyprian pounds and $25 \%$ for the extra incomes.

- A registered company in Cyprus can be either resident of the country for tax purposes so as to be taxed annually with rate $10 \%$ on the net profits or foreign and he is not taxed in Cyprus because the administration is out of the country for more of 165 days per year. It is noticed that a company is considered to be Cyprian company if the decisions and the management take place in Cyprus (for example the board of directors meets in Cyprus). In this case it is recommended the nomination of Cyprian directors.

- They are not liable to tax deduction payments out of country (at companies or juridical persons) whether they are shares, interests or rights.

- Shares and profit from permanent premises out of the country are excluded from the taxation if they fulfill some conditions (the company's administration takes place out of Cyprus and the Managing Directors stay permanently in Cyprus for a period of time less of 180 days per year).

\footnotetext{
${ }^{5}$ Brochure No 20 - Totalserve Management Ltd, Limassol, Cyprus
} 
- Compensation of losses among companies of the same business group is allowed (in case of dependence higher of 75\%). Also the limitation of losses' transfer for only 5 years is revoked.

- Profits which come from sale of real property out of Cyprus releases from taxation.

- The possession of shares by succession in Cyprian offshore company is not burdened with succession duties.

- Reorganizations, mergers and acquisitions of companies are revoked from taxation.

It is important to notice that the tax reform was viewed necessary by Cyprian Government so as to conform the legislation to the Common vested, to achieve compliance with the Code of Ethics about companies' taxation and to effectuate the obligations to OECD.

As far as it concerns other details about companies, we have to comment the following:

- The stock of companies has to be divided at least to one (1) share and to be one standard shareholder who can be natural entity, company or trust ${ }^{6}$ (Antoine, 2005).

The shares can be held by trustees for account of beneficiary shareholders.

\section{Tax Reform's Impacts on Cyprian Offshore Companies}

As it is referred above, since 1975, when Cyprus initiated the estate of offshore companies (Giles, 2004) for first time (Tornaritis, 1984), until 1/1/2003 when the legislation about offshore activities changed, there were 45,000 offshore companies in action.

The most important change was the increase of profits' tax rate from $4.25 \%$ to $10 \%$ which remains the same both for the taxation of incomes from commercial activities in and out of the country.

A research was carried out by Melas, during his doctoral thesis (Melas, 2008), in order to show probable change in offshore companies' behavior, which acted until then in Cyprus, and also the activity of new international business after the tax reform.

\footnotetext{
${ }^{6}$ A trust is begun by someone who is called "trust-giver" and is a mode whereby property ("trustproperty") is held by one or more people ("trustees") for account somebody or for beneficiaries or for specific purposes. Even if trustees are the proprietors of trust-property, they cannot administer it as absolute owners due to the fact that they have the obligation to conform to the terms of law and the trust's report. The property of trust can consists of any kind of asset everywhere in the world. (definition by PriceWaterhouseCoopers - Cyprus as a financial center - the connection with Greece)
} 
The purpose of this research is to highlight and elaborate the problems of tax reform and mainly the shareholders' responses of offshore companies due to change of tax system, transactions' secrecy and confidence among natural persons.

It is obvious that due to extremely big amount of offshore companies which act in Cyprus with Greek interests, the responses have repercussions on Greek economy with relation to reforms of law $3091 / 2002^{7}$ in our country which was initiated in an effort to measure tax evasion and tax avoidance (Melas, 1997) that occurred through offshore companies. The research was conducted through interviews by the use of questionnaires, took apart thirteen consultant's offices that represent 6,068 offshore and international Cyprian companies.

Briefly the results of research are appeared as follows:

\begin{tabular}{|l|l|l|l|l|l|l|l|}
\hline $\begin{array}{l}\text { Consultants' } \\
\text { offices }\end{array}$ & $\begin{array}{c}\text { No of } \\
\text { represe } \\
\text { nted } \\
\text { offshor } \\
\text { e } \\
\text { compan } \\
\text { ies }\end{array}$ & $\begin{array}{c}\text { No of } \\
\text { offshore } \\
\text { companies } \\
\text { which } \\
\text { became } \\
\text { internatio } \\
\text { nal } \\
\text { business }\end{array}$ & $\begin{array}{c}\text { Number } \\
\text { of } \\
\text { offshore } \\
\text { compani } \\
\text { es which } \\
\text { changed } \\
\text { country }\end{array}$ & $\begin{array}{c}\text { Set } \\
\text { Trus } \\
\text { ts }\end{array}$ & $\begin{array}{c}\text { Commercial } \\
\text { reasons to } \\
\text { keep an } \\
\text { offshore } \\
\text { company }\end{array}$ & $\begin{array}{c}\text { Keeping } \\
\text { an } \\
\text { offshore } \\
\text { company } \\
\text { in order to } \\
\text { evade tax }\end{array}$ & $\begin{array}{c}\text { Employed } \\
\text { staff of } \\
\text { offshore } \\
\text { companies }\end{array}$ \\
\hline $\begin{array}{l}\text { Mihailidis } \\
\text { and } \\
\begin{array}{l}\text { Marnerou } \\
\text { C.O. } \\
\text { (Limassol) }\end{array}\end{array}$ & 50 & 0 & 0 & 48 & 0 & 50 & 10 \\
\hline $\begin{array}{l}\text { Abraham } \\
\text { Marios } \\
\text { Partners \& } \\
\text { Go }\end{array}$ & 608 & 0 & 0 & 2 & 608 & 0 & 0 \\
\hline $\begin{array}{l}\text { Ernst \& } \\
\text { Young }\end{array}$ & 500 & 0 & 0 & 175 & 200 & 300 & 40 \\
\hline $\begin{array}{l}\text { Kountouri } \\
\text { and Elisseou }\end{array}$ & 60 & 0 & 0 & 0 & 30 & 30 & 10 \\
\hline Pavlidis & 200 & 60 & 20 & 160 & 20 & 180 & 6 \\
\hline $\begin{array}{l}\text { Ntinos } \\
\text { Antoniou }\end{array}$ & 300 & 270 & 3 & 240 & 30 & 270 & 10 \\
\hline $\begin{array}{l}\text { Price } \\
\text { Waterhouse } \\
\text { Coopers - } \\
\text { Limassol }\end{array}$ & 300 & 200 & 10 & 300 & 75 & 225 & 50 \\
\hline
\end{tabular}

\footnotetext{
${ }^{7}$ Taxation of income individual and legal Entities (Greek Law 2238/1994)
} 


\begin{tabular}{|c|c|c|c|c|c|c|c|}
\hline $\begin{array}{l}\text { Price } \\
\text { Waterhouse } \\
\text { Coopers - } \\
\text { Nicosia }\end{array}$ & 500 & 0 & 0 & 0 & 450 & 50 & 50 \\
\hline $\begin{array}{l}\text { Kiriakou and } \\
\text { Tsiartas }\end{array}$ & 100 & 0 & 0 & 1 & 70 & 30 & 15 \\
\hline $\begin{array}{l}\text { Fotiou and } \\
\text { Efthivoulou } \\
\text { and } \\
\text { Koutsoftas }\end{array}$ & 3.000 & 1500 & 0 & 900 & 1200 & 1800 & 5 \\
\hline $\begin{array}{l}\text { Geniva } \\
\text { Group }\end{array}$ & 350 & 10 & 0 & 0 & 245 & 105 & 30 \\
\hline $\begin{array}{l}\text { Ledra } \\
\text { Management }\end{array}$ & 60 & 20 & 0 & 15 & 54 & 6 & 3 \\
\hline $\begin{array}{l}\text { Nikos } \\
\text { Voskaridis }\end{array}$ & 40 & 0 & 0 & 0 & 4 & 36 & 9 \\
\hline SUM & 6068 & 2060 & 33 & $\begin{array}{l}184 \\
1\end{array}$ & 2986 & 3082 & 238 \\
\hline $\begin{array}{l}\text { AVERAGE } \\
\text { NON } \\
\text { WEIGHTET }\end{array}$ & $\begin{array}{l}466,769 \\
2\end{array}$ & 158,4615 & $\begin{array}{l}2,53846 \\
2\end{array}$ & $\begin{array}{l}141, \\
615 \\
4\end{array}$ & 229,6923 & 237,0769 & 18,30769 \\
\hline $\begin{array}{l}\text { POPULATI } \\
\text { ON }\end{array}$ & 13 & 13 & 13 & 13 & 13 & 13 & 13 \\
\hline MAXIMUM & 3000 & 1500 & 20 & 900 & 1200 & 1800 & 50 \\
\hline MINIMUM & 40 & 0 & 0 & 0 & 0 & 0 & 0 \\
\hline $\begin{array}{l}\text { STANDAR } \\
\text { D } \\
\text { DEVIATIO } \\
\mathrm{N} \\
\end{array}$ & $\begin{array}{l}764,214 \\
4\end{array}$ & 398,0932 & $\begin{array}{l}6,36611 \\
9\end{array}$ & $\begin{array}{l}243, \\
532 \\
6\end{array}$ & 338,0471 & 465,8355 & 17,19778 \\
\hline $\begin{array}{l}\text { INCLINATI } \\
\text { ON }\end{array}$ & $\begin{array}{l}288,087 \\
9\end{array}$ & 18,35165 & $\begin{array}{l}3,95604 \\
4\end{array}$ & $\begin{array}{l}101, \\
428 \\
6 \\
\end{array}$ & 181,4286 & 106,6593 & 17,91209 \\
\hline $\begin{array}{l}\text { VARIATIO } \\
\mathrm{N}\end{array}$ & 616759 & 170047,4 & 35,4359 & $\begin{array}{l}629 \\
70,4 \\
2\end{array}$ & 120165,4 & 231200,9 & 318,2308 \\
\hline
\end{tabular}

\section{Statistical Analysis of Cyprian Law's Effectiveness}

\subsection{The theoretical model}

Let's assume that in capital market are joined n consultants' offices and that each and every one represents a number of offshore companies. Portfolio management depends on degrees of integration as has been pointed out by Thalassinos and Kiriazidis (2003).

The profit of each office is expressed by a function $u$, which depends positively on the number of offshore companies it represents. In other words $u_{i}\left(h_{i}\right)$ where $h_{i}$ is the number of companies that the office represents and $i=1, \ldots, n$. Let for assume convenience that $u_{i}=h_{i}$. 
The variable $h$ is random with probability density function $\varphi(\mathrm{h})$, cumulative distribution function $\Phi(h)$ and values $h_{i} \in R_{+}$. (David, 2008).

As we understand from the model, the existence of offshore companies offers economic benefit to the host country. Specially, it is considered that as the number of offshore companies is increased, the total economic profit is increased too. It is also assumed that the government cares about society's affluence; this means that economic distribution through which all consultants' offices represent a number of off shore companies is preferred to another distribution according to which consultant offices represent any other company. So, society's affluence is expresses by function

Where,

$$
\Omega\left(u_{i}, \ldots, u_{n}\right):=\Omega(h),
$$

$$
\Omega_{i}:=\frac{\partial \Omega}{\partial u_{i}}>0 \text { and } \Omega_{i i}:=\frac{\partial^{2} \Omega}{\partial u_{i}^{2}}<0 \text { for } \mathrm{i}=1, \ldots, \mathrm{n}
$$

It is assumed that government initiates laws in order to improve society's welfare. Thereby, if a law's enforcement in capital market influences the contribution of companies then the law is (economically) efficient as it achieves his goal.

Let $\varphi(h)$ and $\varphi$ '(h) be the contributions of offshore companies before and after the enforcement of a law in the market.

Further, is given the definition of law's efficiency and an empirical method to examine and verify it is introduced.

Definition: A law in capital market is called «efficient» if increases the expected affluence of society. Moreover the law is effective if the following formula $\mathrm{s}$ in force:

$$
\int_{h \in \Re_{+}} \phi^{\prime}(h) \Omega(h) d h>\int_{h \in \Re_{+}} \phi(h) \Omega(h) d h
$$

Proposition: If the following conditions (i) and (ii) are in effect then the law is efficient.

$$
\begin{gathered}
\int_{0}^{h}\left(\Phi(\xi)-\Phi^{\prime}(\xi)\right) d \xi>0, \quad \forall h \in \mathfrak{R}_{+} \\
\int_{0}^{\infty}\left(\Phi(\xi)-\Phi^{\prime}(\xi)\right) d \xi=0 \\
\text { Proof }
\end{gathered}
$$

The conditions (i) and (ii) show that for each value of $h$ the area of cumulative distribution $\Phi^{\prime}$ is smaller than distribution of $\Phi$. In other words $\Phi$ has bigger dispersion than $\Phi^{\prime}$. So it can be said that the conditions (i) and (ii) show that contribution $\varphi$ has higher cusps than $\varphi^{\prime}$. 
It is familiar that function $\Omega$ has maximum to the point where $\bar{V} \Omega(\mathrm{h})=0$ and it is reached when $h_{1}=h_{2}=h_{n}$. This means that function of society's affluence is increased through the decrease of the contribution's $\Phi$ variability.

So, from conditions (i) and (ii) we conclude that average welfare of society increases as variability increases, ceteris paribus and so:

$$
\int_{h \in \Re_{+}} \Omega(h) d \Phi^{\prime}(h)>\int_{h \in \Re_{+}} \Omega(h) d \Phi(h)
$$

or the same

$$
\int_{h \in \Re_{+}} \phi^{\prime}(h) \Omega(h) d h>\int_{h \in \Re_{+}} \phi(h) \Omega(h) d h
$$

which means that law is effective.

The proposition postulates that if average of contributions remains the same then law's effectiveness depends on the decrease of dispersion. Of course, if dispersion remains invariable, then the existence of effectiveness leads to increase of the distribution's average.

In other words the proposition shows that effectiveness of law depends on the comparison of companies' contributions before and after its enforcement. Consequently the efficiency of law can be examined empirically through the assessment of contributions' parameters from which observations are derived.

\subsection{The empirical results}

The variables which are used are:

- $\quad$ LYP $=$ the logarithm of the population of offshore companies for each office before law's enforcement.

- $\quad$ LY1 = the logarithm of the population of offshore companies for each office that did not became Cyprian after law's enforcement.

- $\quad$ LY2 $=$ the logarithm of the population of offshore companies for each office that did not change country after law's enforcement.

- $\quad \mathrm{LY}=$ the logarithm of the population of offshore companies for each office that neither became Cyprian nor changed country after law's enforcement.

- Initially the sample of each variable was examined so as to find from which population comes.

The test of data's adaptiveness in theoretical distributions is done by the use of statistics $X^{2}$. The results are in the Table 1 . 
Table 1: Sample Adaptiveness Test

\begin{tabular}{|l|l|l|l|l|}
\hline Contribution & $\begin{array}{l}\text { Critical Value } \\
\text { (Probability) }\end{array}$ & $\begin{array}{l}\text { Critical Value } \\
\text { (Probability) }\end{array}$ & $\begin{array}{l}\text { Critical Value } \\
\text { (Probability) }\end{array}$ & $\begin{array}{l}\text { Critical Value } \\
\text { (Probability) }\end{array}$ \\
\hline & LYP & LY1 & LY2 & $L Y$ \\
\hline Normal & $8,15(0,017)$ & $3,54(0,170)$ & $2,77(0,250)$ & $3,54(0,170)$ \\
\hline Exponential & $21,06(0,000)$ & $21,09(0,000)$ & $21,05(0,000)$ & $19,53(0,000)$ \\
\hline Gamma & $5,07(0,079)$ & $3,54(0,170)$ & $5,08(0,079)$ & $2,77(0,250)$ \\
\hline Logistic & $5,08(0,079)$ & $3,54(0,170)$ & $5,08(0,079)$ & $2,00(0,368)$ \\
\hline Log-Normal & $5,08(0,079)$ & $3,54(0,170)$ & $5,08(0,079)$ & $2,00(0,368)$ \\
\hline Weibull & $3,54(0,170)$ & $3,54(0,170)$ & $3,54(0,170)$ & $3,54(0,170)$ \\
\hline Laplace & $5,08(0,079)$ & $4,31(0,116)$ & $4,31(0,116)$ & $6,62(0,037)$ \\
\hline
\end{tabular}

Using significance level $10 \%(\alpha=0.1)$, it is founded that null hypothesis is in effect only for Weibull contribution. So the empirical data leads to the conclusion that each variable follows Weibull contribution.

The probability density function of Weibull contribution is: $\frac{\beta x^{\beta-1}}{\alpha^{\beta}} e^{-\left(\frac{x}{\alpha}\right)^{\beta}}$,

Where, $\alpha, \beta>0$ are parameters of contributions.

Also the cumulative probability function is: $1-e^{-\left(\frac{x}{\alpha}\right)^{\beta}}$

The assessment of Weibull parameters by me method of Maximum Likelihood leads to valuators $\hat{\alpha}$ and $\hat{\beta}$ that derives from resolution of the next equation system:

$\hat{\alpha}=\left[n^{-1} \sum_{i=1}^{n} x_{i}^{\hat{\beta}}\right]^{\hat{\beta}^{-1}}, \hat{\beta}=n\left(\hat{\alpha}^{-1} \sum_{i=1}^{n} x_{i}^{\hat{\beta}} \log x_{i}-\sum_{i=1}^{n} \log x_{i}\right)^{-1}$

The values of parameters $\alpha$ and $\beta$ which are found by observations of variables are appeared in Table 2 .

Table 2: Values of Contribution's Parameters

\begin{tabular}{|l|l|l|l|l|}
\hline Value & LYP & $L Y 1$ & $L Y 2$ & $L Y$ \\
\hline (scale) $\hat{\alpha}$ & 5,85331 & 5,4778 & 5,84195 & 5,45326 \\
\hline (shape) $\hat{\beta}$ & 4,77653 & 4,46966 & 4,75234 & 4,38513 \\
\hline
\end{tabular}

From the values, everyone hundredth part $\theta$ can be counted. Especially the estimation of hundredth part $\theta$ of Weibull contribution comes from the connection: 
$P(X \leq k)=\int_{0}^{k}\left[1-e^{-\left(\frac{v}{\alpha}\right)^{\beta}}\right] d v=\theta$

Some values of hundredth parts are appeared in Table 3.

Table 3: Hundred Parts of Contribution

\begin{tabular}{|c|c|c|c|c|}
\hline Hundred Part & $L Y P$ & $L Y 1$ & $L Y 2$ & $L Y$ \\
\hline 5 & 3,143 & 2,818 & 3,127 & 2,770 \\
\hline 10 & 3,654 & 3,311 & 3,638 & 3,264 \\
\hline 25 & 4,509 & 4,145 & 4,495 & 4,106 \\
\hline 50 & 5,421 & 5,047 & 5,408 & 5,016 \\
\hline 60 & 5,747 & 5,372 & 5,735 & 5,346 \\
\hline 75 & 6,268 & 5,893 & 6,258 & 5,875 \\
\hline 90 & 6,970 & 6,602 & 6,963 & 6,596 \\
\hline 95 & 7,365 & 7,002 & 7,359 & 7,004 \\
\hline
\end{tabular}

From the results of the above table it is clear that the following in equation is applied: $\quad \int_{0}^{h} \Phi(\xi) d \xi<\int_{0}^{h} \Phi^{\prime}(\xi) d \xi, \forall h \in \mathfrak{R}_{+}$, which shows the effectiveness of law. So the results appear that in any way law is ineffective.

\subsection{Assessment of linear model}

Let's assumed that $h$ 'is random variable which shows the contribution of offshore companies at consultants' offices after law's enforcement (Pierce D.A. and Schaefer D. W., 1986).

It is assumed also that values $X$ of random variable $h$, before law's implementation, are connected with values $Y$ of variable $h$ ' through the type: $Y=\alpha X^{\beta} \varepsilon$ where $\varepsilon$ is random variable with logarithm - normal distribution and $\alpha$, are parameters of that. Using logarithm the type becomes:

$\log Y=\log \alpha+\beta \log X+\log \varepsilon$ or

$y=c+\beta x+e$

where, $y:=\log Y, x:=\log X, c:=\log \alpha$ and $e:=\log \varepsilon$.

If the law has no influence there are no differences between the values of $h$ ' and $h$. In this case $\alpha=1$ and $\beta=1$ are true.This means empirically that at test of hypothesis $\mathrm{c}=0$ and $\beta=1$ in linear model (1). 
Table 4 shows the results of model's (1) assessment through least squares method.

Table 4: Estimation OLS of Linear Model

$$
\begin{aligned}
& L Y 1=0,32+0,87 L Y P \quad \sigma=0,683 \quad r=0,857 \\
& (0,37)(5,51) \\
& L Y 2=-0,01+0,99 L Y P \quad \sigma=0,031 \quad r=0,999 \\
& (-0,24)(139) \\
& L Y=0,31+0,86 L Y P \quad \sigma=0,720 \quad r=0,843 \\
& (0,34)(5,21)
\end{aligned}
$$

The value of statistic $t$ is in brackets, $\sigma$ is the regression standard error and $r$ is correlation coefficient. It is clear that inclination of linear model is statistically significant in contrast with invariable average which in any way was important.

Next, proof of hypothesis is done:

$H_{o}: c=0, \beta=1$

$H_{1}: c \neq 0$ or $/$ and $\beta \neq 1$

The values of test $\mathrm{X}^{2}$ values of probability and degrees of freedom are showed in Table 5.

Table 5: Test $\mathrm{X}^{2}$

\begin{tabular}{|c|c|c|c|}
\hline & Critical Value & Probability & $\begin{array}{c}\text { Degrees of } \\
\text { Freedom }\end{array}$ \\
\hline$L Y 1$ & 4,6179 & 0,0994 & 2 \\
\hline$L Y 2$ & 1,7769 & 0,4113 & 2 \\
\hline$L Y$ & 4,7333 & 0,0938 & 2 \\
\hline
\end{tabular}

The values of test $F$, the degrees of freedom and the probability's values that comes from regression's residues and the method bootstrapping, are appeared in Table 6.

Table 6: Test F

\begin{tabular}{|c|c|l|c|c|c|}
\hline & $\begin{array}{c}\text { Critical } \\
\text { Value }\end{array}$ & Probability & Bootstrapping & $\begin{array}{c}\text { Bootstrapping:Simulated Normal } \\
\text { Errors }\end{array}$ & D.F. \\
\hline$L Y 1$ & 2,3089 & 0,1455 & 0,632 & 0,149 & 2,11 \\
\hline$L Y 2$ & 0,8884 & 0,4389 & 0,829 & 0,425 & 2,11 \\
\hline$L Y$ & 2,3666 & 0,1397 & 0,659 & 0,125 & 2,11 \\
\hline
\end{tabular}

Using significance level $10 \%$, from tables 5 and 6 , it is comprehensible that according test $X^{2}$ null hypothesis is almost rejected for variables $L Y 1$ and $L Y$. In contrast with this, null hypothesis is accepted in all the cases of test $F$. Because test $\mathrm{X}^{2}$ has gratifying qualities, for large sample, than $\mathrm{F}$, which is preferred for small, 
null hypothesis seems to be supported by data for all the variables. So from tests' results we conclude that law has no influence as it did not change first distribution.

\subsection{Adequacy of linear model}

It is necessary condition, for the empirical solidity of linear model, to view that it is not subsidiary than other no-linear model. Specially, if a no-linear model explains sample's features that linear model cannot then linear model is subsidiary to nolinear. In other words no-linear model offers «information» by empirical observations which cannot be offered by linear model. But if linear model reproduces the results of no-linear, it is viewed that the first has empirical solidity.

So it is not desirable to have some other model, e.g. $\Gamma_{2}$, which explains sample's features that linear model, e.g. $\Gamma_{1}$, cannot. This comparison of samples derives from the need to answer the query whether used model $\Gamma_{1}$ is adequate. The positive answer means that there is no model $\Gamma_{2}$ which has information about sample that are not involved to $\Gamma_{1}$. So, in order to be reliable, model $\Gamma 1$ must not fall short of information in comparison with the competitive models. This practically means that $\Gamma_{1}$ explains results of larger model from which can be derived. Practically model's solidity means that the largest model can lead to estimated linear model without loss of important information.

To decide whether linear model $\Gamma_{1}$ is reliable or not, firstly some no-linear models were studied so as to choose from the data the most reliable e.g. $\Gamma_{2}$. Next, general model $M=\Gamma_{1} \cup \Gamma_{2}$ was created, which consists of information of both models. Consequently, the assumption of $\Gamma_{1}$ linear model's solidity is done by test $\mathrm{X}^{2}$ and shows whether general model can become linear or not, representing it as $M \rightarrow \Gamma_{1}$ where $\Gamma_{1} \subset M$

So as to find a model that explains efficiently empirical data, the model which minimized the sum squares of (studentized) residuals, was chosen. The models are showed in Table 7 .

Table 7: No-linear Models Estimation

\begin{tabular}{|l|lr|ll|}
\hline & Model $\Gamma_{2}$ & & Model $M$ \\
\hline$L Y 1$ & $y=54,5 x^{-7,7 / x}$ & $\sigma=0,673$ & $y=0,92 x+7.10^{-6} x^{78,9 / x}$ \\
& & $r=0,861$ & $\sigma=0,706$ & $r=0,862$ \\
\hline
\end{tabular}




\begin{tabular}{|l|rr|lr|}
\hline$L Y 2$ & & & $y=0,16+0,94 x+5,6.10^{-3} x^{2}$ \\
& & & & \\
& & & & $r=0,0307$ \\
& & & & \\
\hline$L Y$ & $y=55 x^{-7,7 / x}$ & $\sigma=0,708$ & $y=0,91 x+54,5 x^{80,9 / x}$ & \\
& & $r=0,849$ & $\sigma=0,743$ & $r=0,849$ \\
& & & & \multicolumn{2}{c}{} \\
\hline
\end{tabular}

Linear model's solidity test is appeared in Table 8.

Table 8: Linear Model's Solidity Test

\begin{tabular}{|c|c|c|c|}
\hline & Test $X^{2}$ & Probability & D.F. \\
\hline$L Y 1$ & 0,1418 & 0,706 & 1 \\
\hline$L Y 2$ & 0,0012 & 0,972 & 1 \\
\hline$L Y$ & 0,1828 & 0,669 & 1 \\
\hline
\end{tabular}

We understand, from the table, the solidity of linear model which was used and this enhances the conclusions of linear model's estimation.

\subsection{Bayesian study of law's influence}

Using Bayes' regression helps to involve previous information about rates' values to the results of normal regression. Specially, if there is prior information about these values, it can be used to improve posterior estimates.

The model (1) was estimated by Bayes' regression and two basic conditions of prior information. Especially, in the first case, it is assumed that information is diffused because it does not offer essential contribution to specific coefficients' values (diffuse priors). In contrast with this case, in the second one it is assumed that there is essential information which is referred to specific coefficients' values of model (informative priors). The procession of model's (1) estimation and its statistical properties are presented thoroughly by Zellner A. (1971). According to Table 9, Bayes' estimation of model (1) without specific prior information, does not differentiate found values of $\mathrm{c}$ and $\beta$ in relation with classical least squares regression. (see Table 4). 
Table 9: Linear Model's Estimation by Bayes' theory (diffuse priors)

\begin{tabular}{|c|}
$L Y 1=0,3231+0,8698 L Y P$ \\
$(0,336)(4,985)$ \\
$L Y 2=-0,0094+0,9996 L Y P$ \\
$(-0,216)(125,8)$ \\
$L Y=0,3121+0,8667 L Y P$ \\
$(0,308)(4,711)$ \\
\hline
\end{tabular}

Table 10 shows the $95 \%$ (posterior) of confidence interval of $c$ and $\beta$. As it is appeared in this table, these confidence intervals leads to acceptance of hypothesis $c$ $=0$ and $\beta=1$.

Table 10: 95\% Bayes' Confidence Interval (diffuse priors)

\begin{tabular}{|c|c|r|}
\hline & Coefficients & Confidence Interval \\
\hline \multirow{2}{*}{$L Y 1$} & $c$ & $-1,588-2,234$ \\
& $\beta$ & $0,522-1,217$ \\
\hline$L Y 2$ & $c$ & $-0,096-0,077$ \\
& $\beta$ & $0,984-1,015$ \\
\hline$L Y$ & $c$ & $-1,703-2,327$ \\
& $\beta$ & $0,501-1,233$ \\
\hline
\end{tabular}

Because of the fact that the model (1) coefficients' estimations do not show improvement in comparison with classical regression, next they are estimated by the use of information about their probable values. So the initial perception of coefficients' values is included in the process of estimation by the use of contribution function that was assumed previously.

Consequently, Bayes' regression by informative priors is done with the assumption that coefficients $c$ and $\beta$ follow the normal distribution with averages 0 and 1 . The estimations of coefficients that are based on that information are sowed in Table 11. So it is clear that posterior estimations improved the view of coefficients. Especially value of coefficient $c$ was decreased and $\beta$ was increased in relation with previous estimators. Also statistical significance of $\beta$ was improved whether no-significance of co-efficient c was enhanced more.

Table 11: Normal Likelihood Function (informative priors)

\begin{tabular}{|c|}
\hline$L Y 1=0,1173+0,9064 L Y P$ \\
$(0,216)(8,887)$ \\
$L Y 2=-0,0094+0,9996 L Y P$ \\
$(-0,136)(139,3)$ \\
$L Y=0,1044+0,9036 L Y P$ \\
$(0,189)(8,658)$ \\
\hline
\end{tabular}


The same conclusions come from Table 12 which shows the percentage of $95 \%$ (posterior) confidence interval of each coefficient. The estimation of intervals is more accurate as their range is closer than the range of Table's 10 intervals. So the conclusion is that use of Bayes' regression by informative priors led to improvement of estimators' accuracy and enhanced the hypothesis of null average and one point inclination of model (1).

Table 12: 95\% Bayesian Confidence Interval (informative priors)

\begin{tabular}{|c|c|c|}
\hline & Coefficient & Confidence Interval \\
\hline \multirow{2}{*}{$L Y 1$} & $c$ & $-0,960-1,195$ \\
& $\beta$ & $0,704-1,109$ \\
\hline$L Y 2$ & $c$ & $-0,088-0,069$ \\
& $\beta$ & $0,985-1,014$ \\
\hline$L Y$ & $c$ & $-0,994-1,203$ \\
& $\beta$ & $0,696-1,111$ \\
\hline
\end{tabular}

Further use of Bayesian regression's results was done to test the hypothesis of law's no-influence (e.g. $\mathrm{c}=0$ and $\beta=1$ ) through test $\mathrm{F}$.

Table 13: Test $\mathbf{F}$

\begin{tabular}{|c|c|c|}
\hline & Diffuse priors & Informative priors \\
\hline$L Y 1$ & $2,309(0,145)$ & $2,269(0,150)$ \\
\hline$L Y 2$ & $0,889(0,439)$ & $0,889(0,439)$ \\
\hline$L Y$ & $2,367(0,139)$ & $1,367(0,295)$ \\
\hline
\end{tabular}

From table 13, using level of significance $10 \%$, it is seen that test's F results lead again to acceptance of null hypothesis. So, Bayesian data analysis supports that law has no influence to the differentiation of offshore companies' distribution.

\subsection{Trust and law's influence}

This paragraph deals with the factors which influence the number of set trusts. Using Probit analysis it is tested whether the number of trusts is influenced by commercial factors or / and tax-evasion causes. In order to estimate model, variable $I$ is used, which gets values 0 and 1 if observation's value about set trusts is lower or higher than median respectively. This means that variable $I$ divide the observations to two categories: one with small number of trusts, which has value 0 , and the second one which has large number of trusts and value 1 . The Probit estimated model is: $I=\beta X$ where $X$ is independent variable, namely the commercial or tax-evasion factors. The results of Probit regression are appeared in Table 14. 
Table 14: Probit Estimation about Set Trusts

\begin{tabular}{|c|c|}
\hline Commercial Factors & Tax-Evasion Factors \\
\hline$I=2,3 \cdot 10^{-5} X$ & $I=4,6.10^{-3} X$ \\
$(0,027)$ & $(11,6)$ \\
\hline
\end{tabular}

From the table's results we understand that independent variable about commercial factors is statistically non-significant in comparison to the variable referring to taxevasion factors. So the population of trusts depends on tax evasion causes. Moreover, large number of trusts correlates positively with tax-evasion incentives.

Next it is researched whether offshore companies' actions differentiate accordingly to population of set trusts; so according to tax-evasion incentives.

For this purpose model (1) was estimated, without constant term, by least squares method:

$$
\mathrm{Y}=\beta \mathrm{x}+\mathrm{e}
$$

Estimation of coefficient $\beta$ (model 2) appears in Table 15. It is clear from regression results that all estimations of $\beta$ are statistical significant with values close to one point. Furthermore the estimations of correlation coefficients and regression's standard error are not different from the estimations of model (1).

Table 15: OLS Estimation of Linear Model

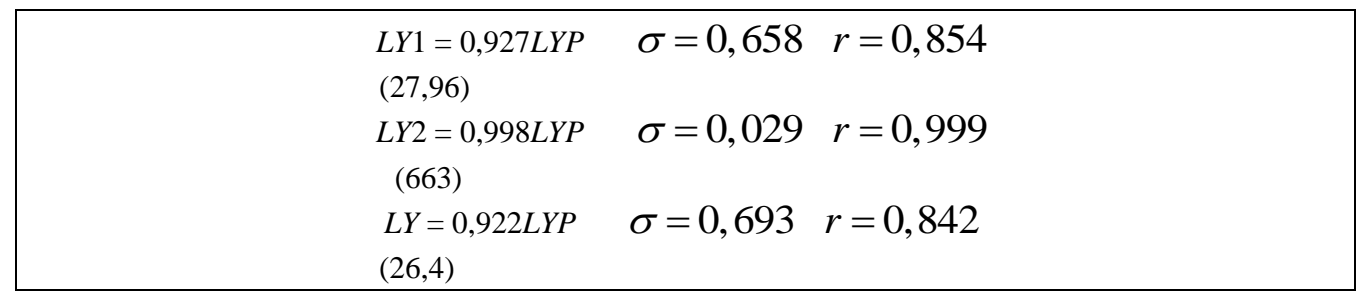

Consequently, empirical conclusions proved the hypothesis of null constant term and one point inclination for model (1); this enhances the conclusions of previous paragraphs about law's no-influence.

The invariability of coefficient $\beta$ was made by Chow test, whereby observations where divided in two subgroups according to variable $I$. So, null hypothesis stage that its value is same for all samples. In other words coefficient's value remains same (invariable) in both subgroups. The acceptance of null hypothesis means that offshore companies with many trusts behave in the same way with the companies which have small population of trusts. 
The results of variable's $\beta$ test constancy are showed in Table 16. Using level of significance $10 \%$ it is concluded that test is important for all the variables except for LY2. This means that null variable becomes accepted only by the observation which concern variable LY2. So empirical results lead to the conclusion that coefficient $\beta$ is not constant for the variables LY1 and LY2. In other words it seems that companies' behavior differ accordingly to the population of trusts.

Table 16: Test Constancy (Chow-break test)

\begin{tabular}{|c|c|c|c|}
\hline & Test $F$ & Test Likelihood ratio & Test Wald \\
\hline$L Y 1$ & $3,829(0,076)$ & $3,883(0,049)$ & $3,829(0,050)$ \\
\hline$L Y 2$ & $1,707(0,218)$ & $1,876(0,171)$ & $1,707(0,191)$ \\
\hline$L Y$ & $4,117(0,067)$ & $4,133(0,042)$ & $4,117(0,043)$ \\
\hline
\end{tabular}

In order to test the solidity of coefficient $\beta$ it was tried to find specific (no-linear) models which explain more efficiently the data of both models. The fitting of model in any sample was achieved based on minimization of least squares sum (studentized) residuals.

Models' estimations, standard error and correlation coefficient are showed in Table 17. From this table it seems that each model fits well to empirical data. Next derivation of each function was counted to the point which is equal to the average of extrinsic variable. In other words we tried to search whether the average change of variable $\mathrm{x}$ has the same influence on internal variable $\mathrm{y}$ without regard to sample. Table 18 appears the variable's $\mathrm{x}$ estimated changes at their average value as they are counted by each sample.

Table 17: Estimation of Gratifying Fitting Model

\begin{tabular}{|c|c|c|c|}
\hline & $I=0$ & & $I=1$ \\
\hline$L Y 1$ & $y=\frac{-84,2 x}{x-90,5}$ & $\begin{aligned} \sigma & =0,156 \\
r & =0,993\end{aligned}$ & $\begin{array}{l}y=(-0,032+0,39 x)^{-1} \\
\quad \sigma=0,897 \quad r=0,836\end{array}$ \\
\hline$L Y 2$ & $y=x$ & & $\begin{array}{r}y=\left(0,54-0,95 x+0,005 x^{2}\right)^{-1} \\
\sigma=0,028 \quad \\
\quad r=0,999\end{array}$ \\
\hline$L Y$ & $y=\frac{-84,2 x}{x-90,5}$ & $\begin{aligned} \sigma & =0,156 \\
r & =0,993\end{aligned}$ & $\begin{array}{l}y=(-0,033+0,4 x)^{-1} \\
\quad \sigma=0,925 \quad r=0,833\end{array}$ \\
\hline
\end{tabular}


From table 18 we see that external variable's influence on internal one is different for LY1 and LY whether is almost the same for LY2. The conclusions of Table 18 agree with Table's 16 results about constancy's test of linear regression variable. So it seems again that companies' behavior with many trusts is not the same with those which have low population of trusts.

Table 18: Estimation of Derivation $\left.\frac{\boldsymbol{d y}}{\boldsymbol{d} \boldsymbol{x}}\right|_{\boldsymbol{x}=\overline{\boldsymbol{x}}}$
\begin{tabular}{|c|c|c|}
\hline & $I=0$ & $I=1$ \\
\hline$L Y 1$ & 1,0423 & 0,7517 \\
\hline$L Y 2$ & 1 & 1,1185 \\
\hline$L Y$ & 1,0423 & 0,7611 \\
\hline
\end{tabular}

\section{Conclusions}

1. Law is (financially) ineffective.

2. There is positive correlation between trust and tax evasion. Especially tax evasion factors lead to high number of trusts.

3. Companies' (consultant offices) behavior with small quantity of trusts seems to be different from the behavior of companies with many trusts.

4. The behavior of companies (consultant offices) with different trust quantity appears to differ before and after law's enforcement. Especially low number trust companies do not change. In contrast with these companies, high number trust companies change their actions. This leads to the conclusion that law probably has influence on companies whose incentive is tax evasion.

5. Translocation of an offshore company in another country is a decision does not seem to be influenced by law's enforcement or by tax evasion factors (it is due to other reasons). On the contrary to this, tax-evasion reasons influenced the decision to turn a company into a Cyprian one.

\section{References}

Antoine, R.M. (2005), Trusts and related Tax Issues in Offshore Financial Law, Oxford, Oxford University Press.

Besley, T. (2006), Principled Agents? The Political Economy of Good Government, Oxford, Oxford University Press.

Breslow N.E., (1996), "Generalized linear models: Checking assumptions and strengthening conclusions", Statistica Applicata, 8, pp.23-41.

Central Bank of Cyprus, International Relations Administration (2001), Cyprus: an international centre of entrepreneurship, Nicosia.

Giles C. (2004), Offshore Tax Planning, Lexis Nexis U.K. 
Draper D. (2008), "Bayesian Variable Selections in Generalized Linear Models under Cost Constraints", ISBA 2008, Australia.

Iliades, Pashalidis, Hatzianastasiou (2003), "Greek company and Cyprian offshore company", Prospectus of the Law Company, September.

Karagiorgos, Th. (2003), Tax Practise (in Greek), Athens: Germanos Publications.

Melas, D. (1997), The Causes of Tax Evasion and her Ways of Reduction, Committee of Researches of Macedonia University, Thessaloniki, Greece.

Melas, D. (2008) The Placement of Greek Capital in Offshore Activities, (in Greek), Ph.D. Thesis, Dept. of Business Administration, University of Macedonia, Thessaloniki, Greece.

Patsalides \& Associates (2003), Tax Reform, September, available at: www.patsalides.com.cy.

Pierce, D.A., and Schaefer, D. W. (1986), "Residuals in generalized linear models“, Journal of the American Statistical Association, 81, pp. 977-986.

Price Waterhouse Coopers (2003), Memorandum on the establishment of a Cypriot company, Nicosia.

Thalassinos, I.E. and Kiriazidis, T. (2003), "Degrees of Integration in International Portfolio Diversification: Effective Systemic Risk", European Research Studies Journal, Vol. VI(1-2), 111-122.

Tornaritis, C. G. (1984), Note on the law of Cyprus relating to offshore operations, shipping opera companies, foreign investments in Cyprus and transit trade, Public Information Office, Cyprus.

Zellner, A. (1971), An introduction to Bayesian Inference in Econometrics, New York: J. Wiley and Sons Inc. 